\title{
DttP Meeting Summaries
}

The GODORT Awards Committee congratulates the winners of its 2017 awards (http://wikis.ala.org/godort/index.php /Announcing_the_2017_GODORT _Awards_Winners):

- James Bennett Childs Award: Judith Russell

- ProQuest/GODORT/ALA "Documents to the People" Award: Florida State University Libraries Government Documents Depository and Mohamed Berray

- Bernadine Abbott Hoduski Founders Award: Philip (Phil) Yannarella

- Margaret T. Lane/Virginia F. Saunders Memorial Research Award: Sarah Potvin and Laura Sare

- NewsBank/Readex/GODORT/ ALA Catharine J. Reynolds Research Grant: Hayley Johnson and Sarah Simms

- W. David Rozkuszka Scholarship: Stephani Rodgers

- Larry Romans Mentorship Award: Lisa Janicke Hinchliffe

This was the inaugural presentation of the Larry Romans Mentorship Award, which is jointly administered with the Gay, Lesbian, Bisexual, and Transgender Round Table (GLBTRT).

The committee was highly impressed by the work with government information being done not only by our winners, but by all who were nominated. The committee encourages GODORT members to recognize colleagues' outstanding efforts by nominating them for an award. Information on individual awards can be found on the GODORT wiki at http://wikis.ala.org/godort/index .php/AboutAwards.

-Kirsten Clark and Kelly Smith, Co-Chairs

\section{Cataloging Committee}

There were three vendors' updates, they are GPO, MARACIVE and HathiTrust. Andrea Morrison, the CC:DA liaison gave an update on the recent CC:DA meeting, mostly on Cataloging rules. The committee reported the updated PPM and is now posted on the GODORT wiki. A working group was formed to update the content on the cataloging toolboxes. The committee agreed to extend the meeting time for thirty minutes longer during the mid-winter meeting to allow more time for discussion on committee business. The annual meeting time will continue to be one hour in length.

\section{- Siu Min Yu}

\section{Development Committee 2016-17}

The Development Committee met virtually several times over the year. Both in 2016 and 2017 we held the annual auction of properties, courtesy of Readex, and raised $\$ 2000+$ each time. In 2017 we also used the ALA Development Office for an email fund solicitation. This was less than successful. A large part of that has to do with the fact that most folks have opted out of email communications from ALA so the list is not robust. The committee will consider a (snail mail) letter campaign in the fall, and also getting ads in DttP.

—Andrea Sevetson

\section{Education Committee}

The GODORT Education Committee met once at ALA Chicago 2017.

The Committee determined that this is the current committee charge and five year goals:

\section{Education Committee Charge}

In order to increase the knowledge and awareness that the library community [needs? Requires?] about government information, the Education Committee shall monitor needs and issues of government information users both inside and outside the library profession, create resources and programs to help meet these needs and resolve these issues in coordination with other organizations working on similar goals.

\section{Five Year Goals:}

1. Revise the Government Information Competencies before ALA Midwinter 2018 in order to clarify which competencies are appropriate for generalists and in order to include egovernment, local government, and competencies that are relevant for public librarians.

2. Once the competencies are revised, raise awareness of them in the library profession over the following two years, including in library schools, by publishing information about them in DttP, on ALA Connect, and speaking about them in forums that are open to nonspecialists in government information. Success will be measured by a steady increase in views of the Government Information Competencies 
on the GODORT wiki as measured by Google Analytics.

3. Propose at least three programs at ALA Annual over the next five years aimed at educating nonspecialist librarians, in order to raise their awareness and knowledge of government information in their own areas of specialty. These programs should be cosponsored by other groups within ALA if possible.

4. Cultivate connections with other parts of ALA by using the affiliations of committee members to propose joint programs and to promote the Competencies.

5. Monitor the educational offerings of other organizations, like the North Carolina Library Association's Accidental Government Information series and GPO's FDLP Academy, in order to provide complementary programming rather than duplication.

6. After the competencies are revised, thoroughly review the GODORT Exchange, archiving dated content and soliciting new content. All sections of the Exchange should be current before ALA Annual 2019.

7. Once the GODORT Exchange is updated, committee members will promote the Exchange by monitoring GOVDOCL for questions that can be answered using the Exchange and replying with a link to the Exchange. Success will be measured by a steady increase in use of the Exchange, monitored using Google Analytics.

There was discussion on the concept of "goals." The committee agreed that something measurable objectives should be determined. Conversation will continue between conventions. If you would like to participate in that conversation, please contact Education Committee Chair Gwen Sinclair.

We briefly discussed the pedagogy of Threshold Concepts as it relates to government information research.

—Jill Vasalakos-long

\section{International Documents Task Force}

The International Documents Task Force held a virtual meeting on June 20, 2017, in lieu of an in-person meeting at ALA Annual.

The recording of the entire meeting is available via Adobe Connect, http:// ala.adobeconnect.com/plu4zfzlzoof/. (Please note, you need to download the Adobe Connect app to view.)

Minutes from the meeting as well as the Agency Liaison Report are available via the GODORT IDTF wiki page: http://wikis.ala.org/godort/index.php /International_Documents.

A panel from the UN Dag Hammarksjöld Library joined us for the full hour. Thanos Giannokopoulos, Chief Librarian, and Bojan Grozdanic, Digital Library Coordinator, provided an overview of the UN Digital Library that just launched in May, https://digitallibrary .un.org/. There is a YouTube video that provides an overview https://www.you tube.com/watch?v=HUuM44pkklU.

Ramona Kohrs, Outreach and Depository Library Coordinator, went over the results from the UN Depository Library Training Needs Assessment Survey. Most of the respondents would like some type of online training modules or webinars. There is interest in training on UN research tools, UN Documentation, statistical tools, subject based training (i.e., human rights, refugees and migration). The hope is for some type of training (webinar for example) to happen by the end of 2017.

—Kris Kay and Susan Paterson

\section{Legislation Committee}

The Legislation Committee met twice during Annual. Saturday's session was a joint meeting with the ALA Committee on Legislation's Government Information Subcommittee (COL-GIS). The first part of the meeting was devoted to updates from GPO by David Walls, Preservation Librarian. Next, Gavin Baker, the new Assistant Director in the Office of Government Relations at ALA Washington Office, introduced himself and gave an update on the Washington Office's recent activities. As these updates took up the majority of the meeting time, it was determined that GODORT would schedule a webinar featuring Baker in early fall to discuss advocacy and how to effectively advocate for issues of interest to our members.

Sunday's meeting was devoted to discussion of the results of the brief survey the Legislation Committee issued in June. Committee members and meeting attendees went through the survey responses and identified common themes, which will help inform the Committee's work in the coming years. The survey results and common themes identified at this meeting will be posted on the Committee's page on the GODORT wiki (http://wikis.ala.org /godort/index.php/Legislation).

—Hallie Pritchett 


\section{Preservation Working Group}

With the dedicated work of the Preservation Working Group, GODORT was able to present two programs at Annual 2017.

The first one, "Government information preservation: collections and collaboration," was cosponsored by the Federal Documents Task Force and featured discussions about collaborative approaches to collecting and preserving government information in all formats. Susanne Caro moderated the discussion, and Anne Harrison (FEDLINK), Roberta Gebhardt (Montana Historical Society), Robbie Sittel (University of North Texas), and James R. Jacobs (Stanford University) presented on projects at the state and national levels.

The second program, "Government publications preservation in action: how it works and what it costs," explored digitization projects and the Federal Information Preservation Network (FIPNet) and was moderated by Bernadine Abbott Hoduski. The program featured presentations by Barbara Sagraves (Dartmouth College), "A Case History on the Readex and Dartmouth Serial Set Digitization Project"; Benjamin Walker (University of Florida), "Centers of Excellence at the University of Florida: Preserving and Digitizing the Panama Canal papers"; and Kate Tallman (University of Colorado-Boulder) "Preservation stewardship in the Federal Information Preservation Network (FIPNet)." GODORT also hosted a reprise of its successful Research Round Robin, an informal meeting for sharing and discussing research with government information, and the management of these collections to support emerging research.

—Shari Laster

\section{State and Local Documents Task Force (SLDTF)}

The State and Local Documents Task Force discuessed the possibility of updating and expanding the State Depository Systems on the GODORT Wiki: http://wikis.ala.org/godort/index.php /State_Depository_Library_Systems. We discussed the possibility of expanding it to include any government documents groups in the state library associations (or outside of them), as well as any state or local listservs for government information. We also discussed the need to recruit government documents librarians for GODORT committees and activities. This will be particularly important when we do any projects, as we will need volunteers to help us.

We also welcome Jane Canfield as the new SLDTF Coordinator.

—Sonnet Ireland, SLDTF Coordinator 